\title{
Modification of NMDA Receptor Channels and Synaptic Transmission by Targeted Disruption of the NR2C Gene
}

\author{
Alexander K. Ebralidze, ${ }^{1}$ David J. Rossi, ${ }^{2}$ Susumu Tonegawa, ${ }^{1}$ and N. Traverse Slater ${ }^{2}$ \\ ${ }^{1}$ Center for Learning and Memory, Massachusetts Institute of Technology, Cambridge, Massachusetts 02139-4307, and \\ 2Department of Physiology, Northwestern University Medical School, Chicago, Illinois 60611-3008
}

A novel strain of mutant mouse has been generated with a deletion of the gene encoding the NR2C subunit of the NMDA receptor, which is primarily expressed in cerebellar granule cells. Patch-clamp recordings from granule cells in thin cerebellar slices were used to assess the consequences of the gene deletion. In granule cells of wild-type animals, a wide range of single-channel conductances were observed (19-60 pS). The disruption of the NR2C gene results in the disappearance of low-conductance NMDA receptor channels ( $<37$ pS) normally expressed in granule cells during developmental maturation. The NMDA receptor-mediated synaptic current is markedly potentiated in amplitude, but abbreviated in duration (with no net difference in total charge), and the non-NMDA component of the synaptic current was reduced. We conclude that the NR2C subunit contributes to functional heteromeric NMDA receptor-subunit assemblies at the mossy fiber synapse and extrasynaptic sites during maturation, and the conductance level exhibited by a given receptor macromolecule may reflect the stochiometry of subunit composition.

Key words: cerebellum; granule cells; NMDA receptors; synaptic transmission; patch-clamp; gene knockout
The NMDA subtype of glutamate receptor plays an important role in a number of neuronal functions including synaptic transmission, synaptic plasticity, and the migration and use-dependent synapse stabilization of neurons during development (Constantine-Paton et al., 1990; Bliss and Collingridge, 1993; Bear and Malenka, 1994; Garthwaite, 1994; Slater and Rossi, 1996). Five subunits of NMDA receptor have been cloned (rat: NR1, NR2A-D; mouse: $s 1, \epsilon 1-4)$, which, based on sequence homology, pharmacology, and biophysical properties, make up the NMDA receptor subfamily (Kutsuwada et al., 1992; Meguro et al., 1992; Monyer et al., 1992, 1994). Functional NMDA receptor channels in situ appear to be formed by the heteromeric expression of NR1 with one or more NR2 subunits. Each NR1-NR2 subunit combination will impart unique properties to the receptor-channel complex, in terms of the gating kinetics, unitary conductance, binding affinity, and kinetics of desensitization (Meguro et al., 1992; Stern et al., 1992; Monyer et al., 1994). These properties of receptor channels will be reflected in the ensemble behavior of the receptors at synaptic and extrasynaptic locations. Thus, the molecular composition of NMDA receptors in a given cell will have profound consequences for the physiological behavior of the neuron.

In the cerebellum, striking changes in the expression of NR2 subtype mRNAs accompany the developmental migration and postmigratory maturation of granule cells. During migration and immediately after arrival in the internal granular layer, only the NR2B subunit is expressed, and this expression then declines to

\footnotetext{
Received March 22, 1996; revised May 29, 1996; accepted June 3, 1996.

This work was supported by grants from the U.S. Public Health Service (S.T., N.T.S.) and the Office of Naval Research (N.T.S.). We are grateful to Drs. N. Agoypan, S. G. Cull-Candy, and M. Farrant for helpful discussions, and to Drs. David Attwell and Enrico Mugnaini for comments on this manuscript.

Correspondence should be addressed to Dr. N. Traverse Slater, Department of Physiology M211, Northwestern University Medical School, 303 East Chicago Avenue, Chicago, IL 60611.

Dr. Rossi's present address: Department of Physiology, University College London, Gower Street, London WC1E 6BT, UK.

Copyright (C) 1996 Society for Neuroscience $0270-6474 / 96 / 165014-12 \$ 05.00 / 0$
}

undetectable levels in the adult (Watanabe et al., 1992, 1994b; Monyer et al., 1994). Expression of the NR2A subunit appears during the formation of synaptic contacts and finally, a heavy expression of NR2C subunits appears during synaptic pruning (Monyer et al., 1994; Watanabe et al., 1994a). These changes in subunit expression are matched by changes in the properties of NMDA receptor channels recorded in outside-out patches. During the period before the expression of NR2C, only channels of relatively large unitary conductance $(40-50 \mathrm{pS})$ are seen (Rossi and Slater, 1993; Farrant et al., 1994), whereas after this period, smaller-conductance channels also are observed (Farrant et al., 1994). Because recombinant expression studies of oocytes transfected with NR1-NR2A or NR1-NR2B cDNAs yield functional NMDA receptor channels of large conductance, whereas oocytes expressing NR1-NR2C subunits display channels of smaller conductance (Stern et al., 1992), it has been suggested that the low-conductance channels recorded late in cerebellar development represent the expression of NMDA receptor channels made up of an NR1-NR2C subunit composition (Farrant et al., 1994). The expression of NR2C also coincides with a reduction of the proportional contribution of NMDA receptors to the synaptic current at the mossy fiber-granule cell synapse (D'Angelo et al., 1993). In the present study, we have used gene-targeting methods to disrupt expression of the NR2C gene, which normally is most heavily expressed in cerebellar granule cells, and examined the properties of individual NMDA receptor channels and macroscopic synaptic currents in situ.

\section{MATERIALS AND METHODS}

Construction of the targeting vector. A mouse 129/SV genomic library was screened with the mouse DNA fragments amplified by the polymerase chain reaction. A phage clone was isolated containing the $15 \mathrm{~kb}$ DNA fragment that included all four putative transmembrane segments (M1M4, amino acids 434-815) (Kutsuwada et al., 1992), as demonstrated by partial sequencing, restriction enzyme mapping, and Southern hybridization. To construct the targeting vector, segment M2 was substituted with the 1.8 pgk-neo gene cassette derived from PMC1NEO (Stratagene, La 
Jolla, CA). The resulting construct was amplified, purified, and linearized before introduction into embryonic stem (ES) cells.

Targeting experiments. A D3 mouse ES cell line was cultured on a monolayer of mitotically inactivated LIF-producing STO feeder layers as described (McMahon and Bradley, 1990). Cells were trypsinized, resuspended at a concentration of $10^{7}$ cells $/ \mathrm{ml}$ in PBS, and electroporated with a Bio-Rad Gene Pulcer $(800 \mathrm{~V}, 3 \mathrm{mF}$ with a $0.4 \mathrm{~cm}$ electrode distance) using $50 \mu \mathrm{g}$ of DNA. Cells were immediately plated after transfection, allowed to recover for $24 \mathrm{hr}$, and grown in the presence of G418 (200 $\mu \mathrm{g} / \mathrm{ml}$ ) for $8 \mathrm{~d}$. Chimeras were generated as described (Bradley, 1987). $\mathrm{C} 57 \mathrm{BL} / 6 \mathrm{~J}$ blastocysts were isolated at day 3.5 and injected with 15-20 ES cells. Mice heterozygous for the mutation (NR2C $+/-$ ) were obtained by crossing the chimeras to $\mathrm{C} 57 \mathrm{BL} / 6 \mathrm{~J}$ mice. The heterozygotes were intercrossed further to obtain the mutation homozygotes. The mice then were genotyped by Southern blot analysis of tail DNA.

Preparation of brain slices. Patch-clamp recordings from visually identified granule cells in thin cerebellar slices obtained from C57BL/6J mice or Sprague-Dawley rats were performed as described previously (Edwards et al., 1989; Silver et al., 1992; Rossi and Slater, 1993; Rossi et al., 1995). Animals of either sex, age 14-18 postnatal (P) d were anesthetized using Isoflurane by inhalation, and killed by decapitation using a small animal guillotine while under general anesthesia. The brain was removed rapidly by dissection and placed in an ice-cold $\left(0-5^{\circ} \mathrm{C}\right)$ extracellular solution of the following composition (in mM): $\mathrm{NaCl} 124, \mathrm{KCl} 3, \mathrm{CaCl}_{2}$
2.4, $\mathrm{MgSO}_{4} 1.3, \mathrm{NaH}_{2} \mathrm{PO}_{4} 1.25, \mathrm{NaHCO}_{3} 26$, and D-glucose 10 (gassed with $\left.95 \% \mathrm{O}_{2} / 5 \% \mathrm{CO}_{2}\right), \mathrm{pH}$ 7.4. Thin $(150 \mu \mathrm{m}$ thick) parasagittal slices of cerebellar vermis were cut and maintained at room temperature after an initial hour of incubation until needed for recording. For recording, slices were placed in a submersion chamber on the stage of an upright microscope (Leitz Laborlux) and viewed with a Zeiss $40 \times(0.75$ numerical aperture) water immersion objective with Hoffman Contrast Optics. The slices were perfused continuously throughout the experiment with external medium at room temperature $\left(20-22^{\circ} \mathrm{C}\right)$.

Patch-clamp recording and synaptic stimulation. Patch recording pipettes were constructed from thick-walled borosilicate glass capillaries (direct current resistance 4-12 $\mathrm{M} \Omega$ ) and were filled with an internal solution containing (in mM): $\mathrm{K}$ gluconate $145, \mathrm{MgCl}_{2} 2, \mathrm{~K}_{2} \mathrm{ATP} 5$, EGTA 0.1 , and HEPES 5, $\mathrm{pH}=7.2$, osmolarity adjusted to $290 \mathrm{mOsm}$ ). Patch pipettes were coated with SYLGARD resin (Dow Corning, Midland, MI), mounted in the headstage input of a stage-mounted micromanipulator, and positioned over the soma of the neuron by visual control. To construct $I-V$ curves of synaptically activated conductances, K gluconate was replaced by cesium methanesulphonate $(145 \mathrm{~mm})$ and QX-314 (10 mM) to block voltage-gated $\mathrm{K}^{+}$and $\mathrm{Na}^{+}$currents, respectively. Transmembrane voltage and current were recorded using an Axopatch 1D amplifier (filtered at $10 \mathrm{kHz} ;-3 \mathrm{~dB}$ ), stored on video tape (VR-10C, Instrutec), and played back off-line for analysis using pClamp (v.6.0.1) software (Axon Instruments, Foster City, CA) running on a PC-

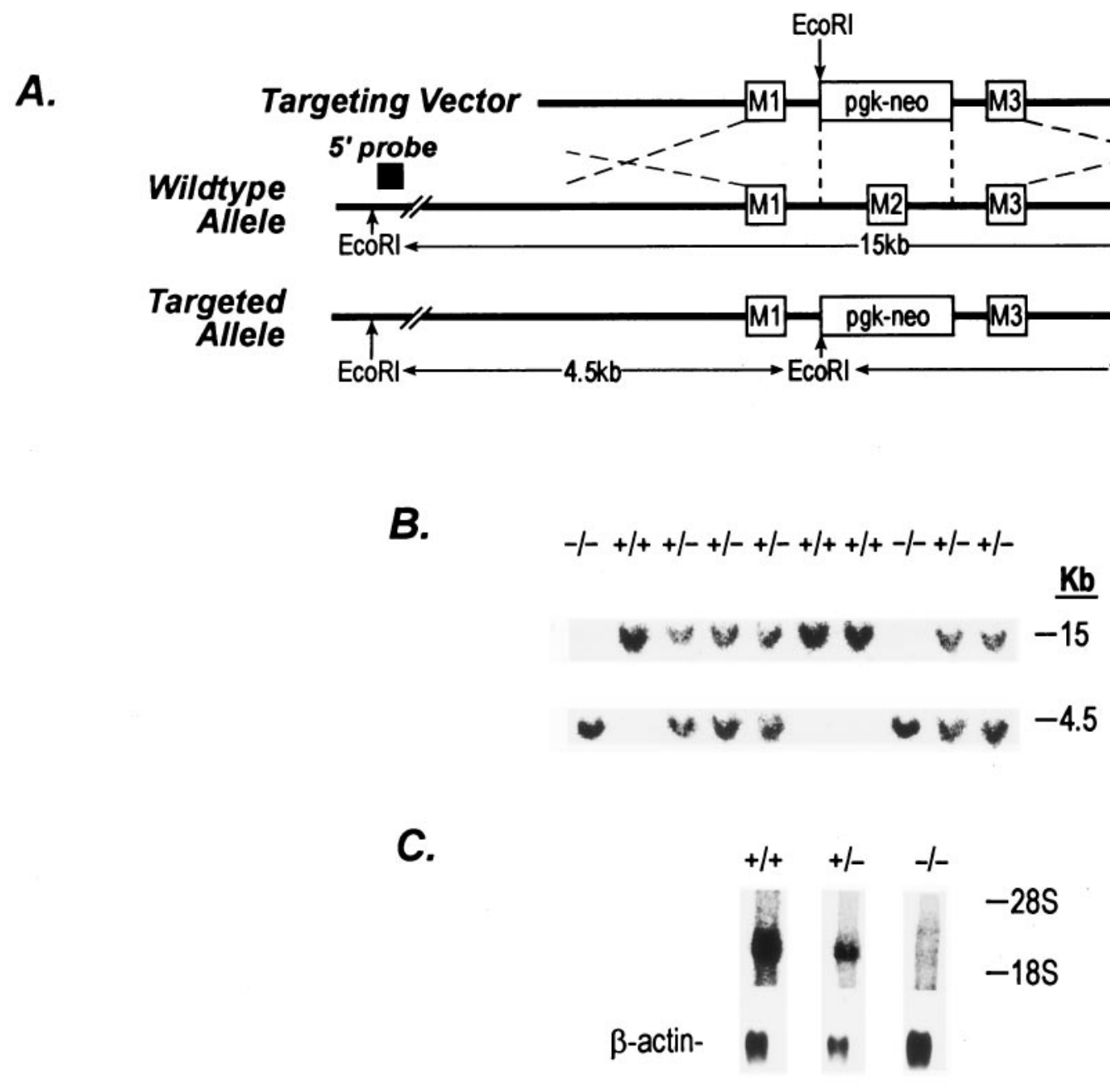

Figure 1. Targeted disruption of the NR2C gene. A, Schematic representations of the targeting vector, wild-type allele, mutant allele, and the strategy for NR2C knockout. Four putative segments (M1-M4) are shown as open boxes. The location of the $5^{\prime}$ - and $3^{\prime}$-external probes is shown. Both probes hybridize to a $15 \mathrm{~kb} E c o$ RI fragment from the wild-type allele and to 4.5 and $10.5 \mathrm{~kb} E c o$ RI fragments from the mutated allele, respectively. $B$, Southern blot analysis of progeny from intercross of heterozygotes (NMDA $2 \mathrm{C}+/-$ ). $5^{\prime}$-External probe was used in this experiment. A similar result was obtained using the $3^{\prime}$-external probe (data not shown). $C$, Northern blot analysis of wild-type and mutated mice. Poly $\left(\mathrm{A}^{+}\right) \mathrm{RNA}$ was isolated from total brain tissue from 4-d-old animals. RNA was separated in a formaldehyde gel and transferred to a nylon membrane (Hybond-N+, Amersham). Membrane was hybridized with a fragment of NR2C cDNA containing all four transmembrane segments. The same filter was rehybridized with a $\beta$-actin probe. 
compatible 486 microcomputer (Dell 450/1). In whole-cell recordings, the access resistance $\left(R_{\mathrm{a}}\right)$ was estimated from measurements of membrane capacitance $\left(C_{\mathrm{m}}\right)$ and the time constant of the capacity current in response to voltage steps $(\tau)$ (Marty and Neher, 1983), where $R_{\mathrm{a}}=\tau / C_{\mathrm{m}}$, and was monitored continuously throughout the experiment. The very small size and consequent electrotonic compactness of granule cells (Mugnaini et al., 1974; Silver et al., 1992; D'Angelo et al., 1993; Gabbiani et al., 1994) allow one to directly visualize single-channel events in the whole cell, providing a unique opportunity to correlate the molecular composition of NMDA receptor channels with the behavior of an intact nerve cell. All single-channel records were filtered at $2 \mathrm{kHz}$ and analyzed manually with a threshold detection set at $\sim 50 \%$ of the open-channel amplitude (determined by a Gaussian fit). In the majority of experiments, single-channel conductance levels were calculated from the slope of the current amplitudes over a range of membrane potentials with respect to the measured reversal potential (see Figs. $2 D, 5 D, 7 C$ ) after subtraction of liquid junction potentials. After analysis, some records were filtered at $1 \mathrm{kHz}$ for clarity of display.

Concentric bipolar tungsten stimulating electrodes (Rhodes Medical
Instruments, Woodland Hills, CA) were placed in the white matter to activate mossy fiber inputs to granule cells. Care was taken to place the stimulating electrode at locations within the white matter remote from the recording pipette to avoid contaminating the rising phase of the fast synaptic response by the stimulus artifact. In all experiments, stimuli of $100 \mu \mathrm{sec}$ duration were used and were conducted in the presence of bicuculline $(10 \mu \mathrm{M})$ to block $\mathrm{GABA}_{\mathrm{A}}$ receptor-mediated inhibitory synaptic currents from neighboring Golgi cells. Measurements of the NMDA receptor-mediated EPSCs in granule cells were made in the presence of both CNQX $(10 \mu \mathrm{M})$ and glycine $(10 \mu \mathrm{M})$.

\section{RESULTS}

\section{Production of the NR2C knockout mutant}

To introduce an NR2C null mutation by homologous recombination in mouse ES cells, a replacement vector was generated in which the M2 segment, which has been proposed to be a hairpin pore region (Wo and Oswald, 1995; Wood et al., 1995), was

\section{$+/+$ Whole-cell recording}
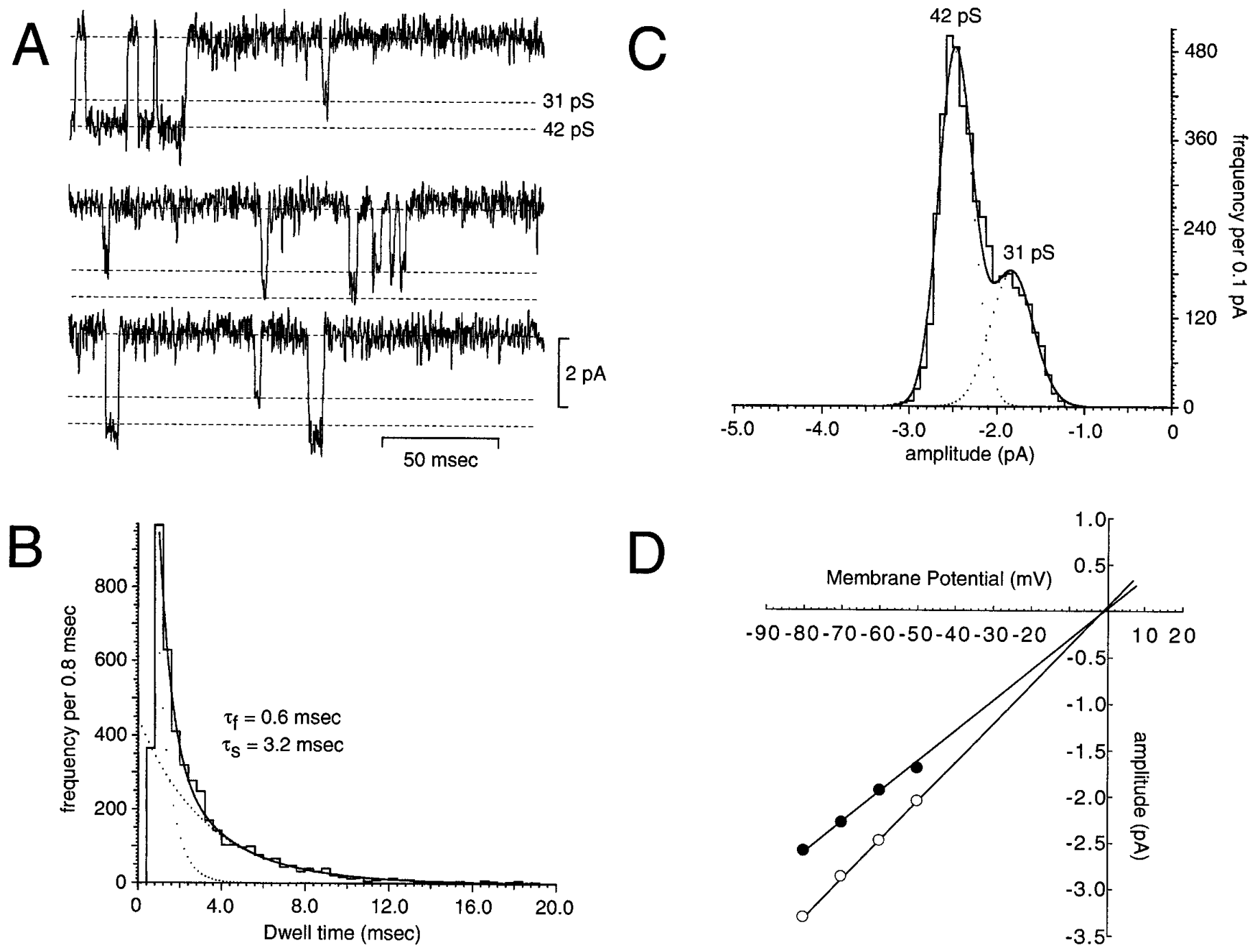

Figure 2. Whole-cell recording of spontaneous NMDA receptor channels in mature wild-type granule cells. $A$, Representative records of spontaneous NMDA receptor-mediated currents in a mature wild-type mouse granule cell. Two channel opening events with distinct unitary conductance and gating kinetics are clearly resolvable. $B$, Dwell-time distribution of open times with the fit of a double exponential (solid line) superimposed. $C$, Amplitudefrequency histogram with the fit of a double Gaussian distribution superimposed. Both conductances have extrapolated reversal potentials near $0 \mathrm{mV}(D)$ and have corresponding conductances of 42 and $31 \mathrm{pS}$. All data were recorded in the same granule cell voltage-clamped at $-60 \mathrm{mV}$ in the absence of extracellular $\mathrm{Mg}^{2+}$. 


\section{+/+ Excised patch recording}
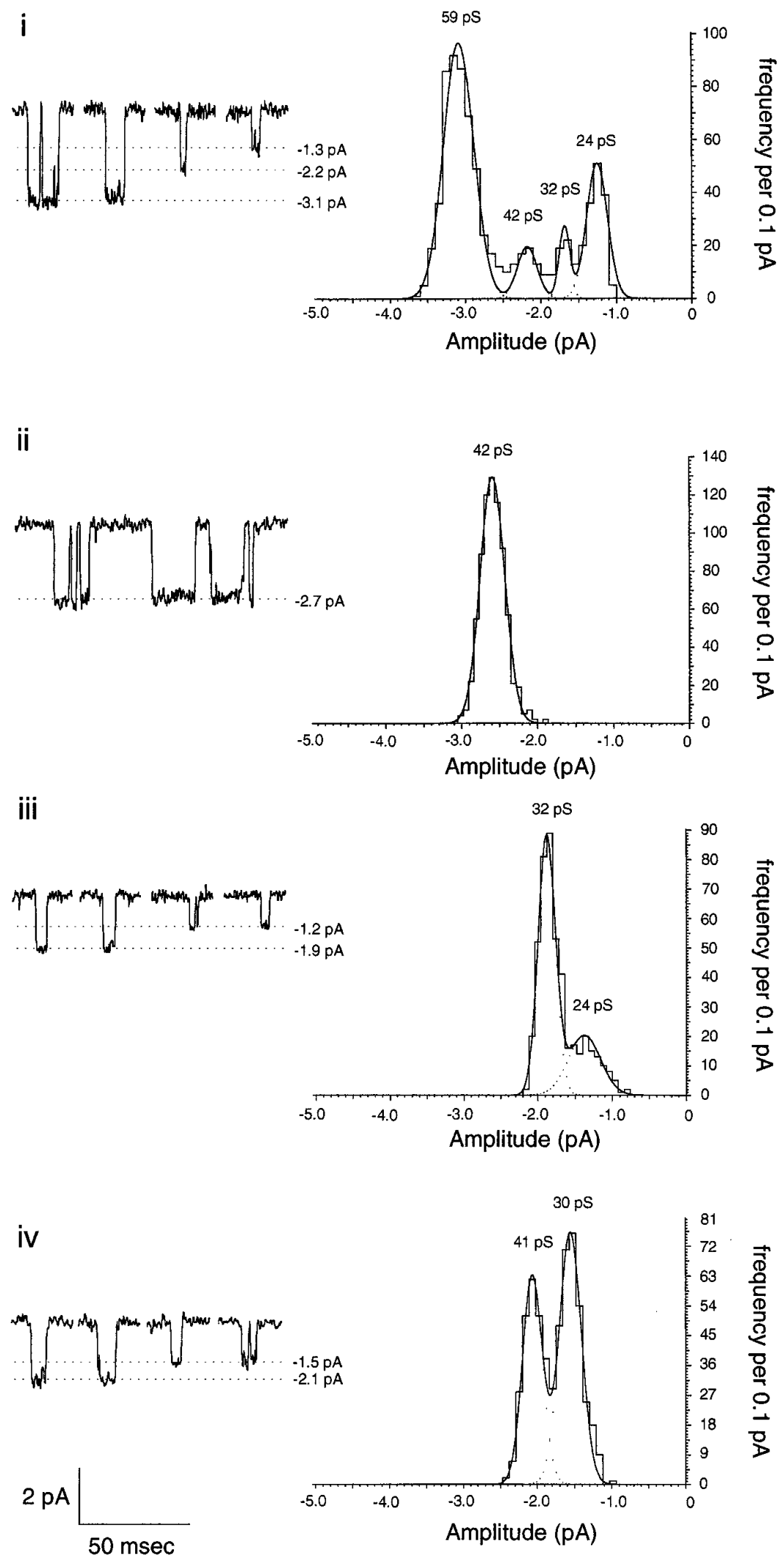

Figure 3. NMDA receptor channels in excised outside-out patches from mature wild-type granule cells. Left traces illustrate representative examples of the conductance levels displayed by NMDA-activated channels in excised patches from four wild-type granule cells. Right graphs illustrate the amplitude-frequency histogram of a larger data set obtained from the patch shown to the left. Conductance levels in picosiemens for each patch reflect the estimated conductance after subtraction of junction potentials and estimation of the reversal potential (as in Fig. 2D). 
replaced by a neomycin resistance cassette (pgk-neo) (Fig. $1 A$ ). The pgk-neo cassette was used as a positive selection marker. The targeting vector contained $6.7 \mathrm{~kb}$ of homologous sequences from the NR2C gene locus. A D3 mouse ES cell line was transfected with the linearized targeting vector, and the cells were selected for resistance to $\mathrm{G} 418$ for $8 \mathrm{~d}$. Of the $288 \mathrm{ES}$ clones analyzed, 5 were found to have the targeted mutation. All five of the recombinant ES clones were injected into $\mathrm{C} 57 \mathrm{BL} / 6 \mathrm{~J}$ blastocysts, and two of these clones yielded male and female chimeric mice that transmitted the targeted allele through the germline (Fig. $1 B$ ). Intercross between the heterozygotes gave rise to homozygotes and wild types at the expected frequency of 1:2:1 (Mendelian inheritance). To confirm that the mutation introduced into the NR2C gene was in fact a null mutation, littermates from heterozygous intercrosses were subjected to Northern blot analysis, which detected no NR2C mRNA in the brain of NR2C $-/-$ mice (Fig. $1 C$ ). Both male and female mutant mice displayed normal fertility and developed normally without any obvious disturbances of health, motor activity, or behavioral problems.

\section{Single NMDA receptor-gated channels in mouse granule cells}

Single NMDA receptor-activated channels in granule cells were studied in wild-type and homozygous mutant mice using both whole-cell recording of tonic channel activity, and in excised outside-out patches from the cell soma. The tonic activation of NMDA receptor channels could be readily visualized in whole-cell recordings of mouse granule cells. This tonic NMDA receptorchannel activity has been described previously in rat granule cells (Rossi and Slater, 1993; Slater and Rossi, 1996), and is believed to originate from a paracrine release of glutamate within developing cerebellum (Komuro and Rakic, 1993). Because of the small size and electrical compactness of granule cells, the opening of single NMDA receptor channels in response to the binding of glutamate at all locations on the neuron can be observed. In older $(>\mathrm{P} 14)$ wild-type mice, spontaneous NMDA receptor-mediated singlechannel events could be recorded, which displayed a wide range of conductance levels that correspond to the high- and lowconductance channels observed previously in excised patches from the soma of mature wild-type rat granule cells (Farrant et al., 1994). In many neurons, the tonic activation of both high- and low-conductance levels could be visualized simultaneously (Fig. 2), and Gaussian fits of the current amplitude distributions yielded 2-4 peaks. Dwell-time histograms also revealed two characteristic open times (Fig. $2 B$ ). These observations are consistent with the conclusion that mature granule cells express two distinct populations of NMDA receptor channels: a large-amplitude and longeropen time population, and a population characterized by a smaller-conductance level and shorter open time, corresponding to the expression of NR1-NR2A and NR1-NR2C subunit combinations, respectively (Stern et al., 1992; Farrant et al., 1994). It should be noted that the measured conductance levels observed in this study are $\sim 10 \mathrm{pS}$ lower than those reported in other studies in which a lower extracellular calcium concentration ( $\leq 1 \mathrm{~mm})$ was used (Howe et al., 1991; Gibb and Colquhoun, 1992; Silver et al., 1992; Farrant et al., 1994), but are similar to the largeconductance level in the presence of $2.5 \mathrm{~mm}$ extracellular calcium in rat neurons (Gibb and Colquhoun, 1992; Rossi and Slater, 1993; Slater and Rossi, 1996).

Excised outside-out patches from the soma of mature $+/+$ mouse granule cells exposed to bath-applied NMDA (10-50 $\mu \mathrm{M}$ with $10 \mu \mathrm{M}$ glycine) also displayed a wide range of conductance levels (Fig. 3). Some patches displayed only large (Fig. 3ii)- or small (iii)-conductance openings, whereas others displayed both types of channel in varying proportions (Fig. 3i,iv). When the peaks of Gaussian fits of individual recordings (both whole cell and excised patch) of mature $+/+$ mice were plotted with respect to their frequency of occurrence (Fig. $4 A$, derived from 33 granule cells in 23 different animals), it can be seen that there is a wide spectrum of conductance levels across the population of wild-type cells, rather than discrete peaks at high- and low-conductance levels. This would suggest that individual channels in vivo are made up of different combinations of all three subunits, rather than two distinct populations of channels made up of only two subunit types (e.g., NR1-NR2A or NR1-NR2C).

Recordings from mature ( $>$ P14) granule cells of homozygous mutant mice revealed a different pattern (Fig. 4B) (derived from whole-cell and excised patches of $13-/-$ granule cells from eight mice). In whole-cell recordings (Fig. 5), only large-amplitude opening events were observed (37-53 pS), and dwell-time histo-
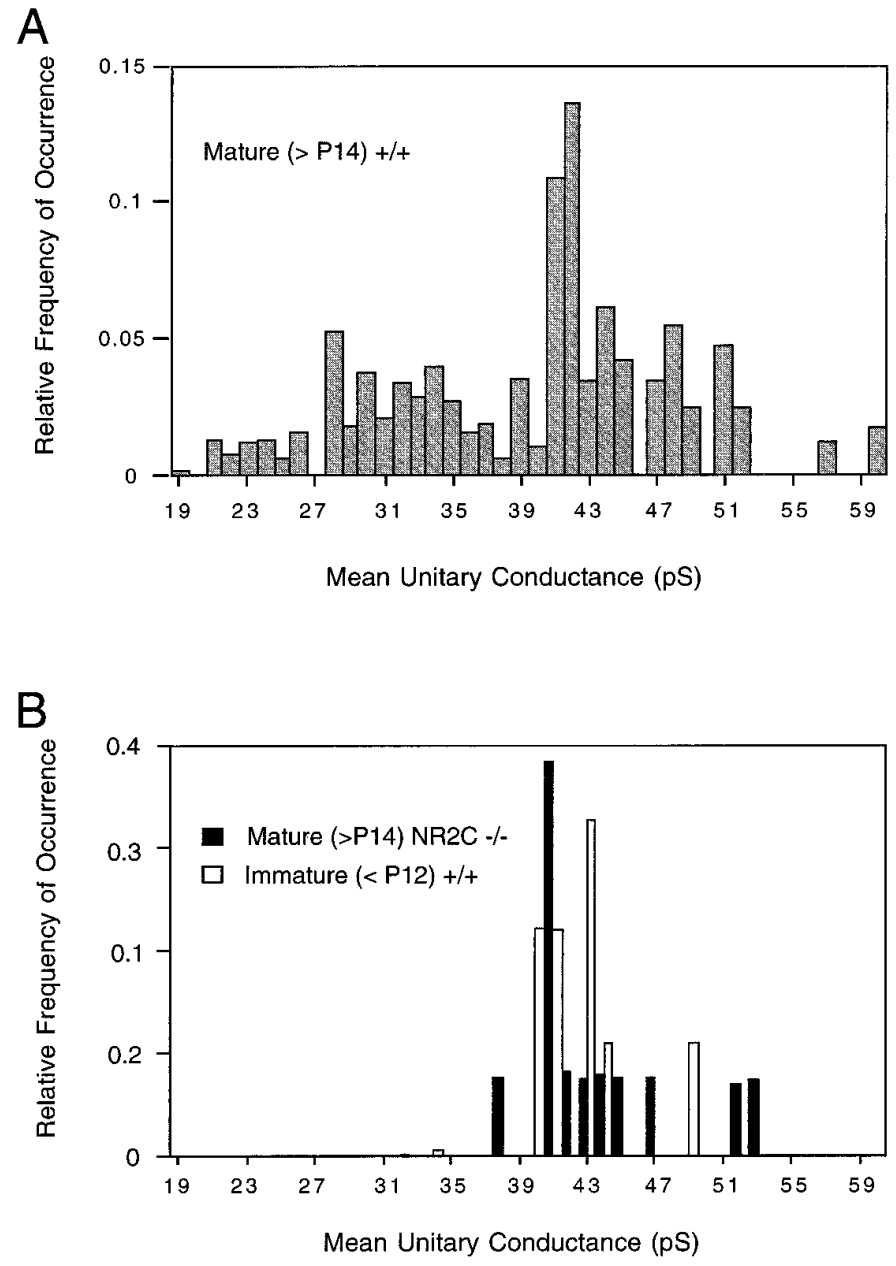

Figure 4. The distribution of conductance states expressed by $-/-$ mice is very similar to that observed in young rats. $A$, The proportional distribution of measured conductance levels in mature ( $>$ P14) wild-type mouse granule cells. $B$, The proportional distribution of measured conductance levels in mature $(>P 14)$ homozygous mutant $(-/-)$ mouse granule cells ( filled columns) and those measured in young $(<\mathrm{P} 12)$ rat granule cells. All three groups show similar distributions of conductances of $>39 \mathrm{pS}$. There is a marked difference in the distribution of conductances of $<39 \mathrm{pS}$. The $-/-$ mice appear to more closely resemble the young wild types and completely lack the low-conductance NMDA receptor channel. 


\section{-/- Whole-cell recording}
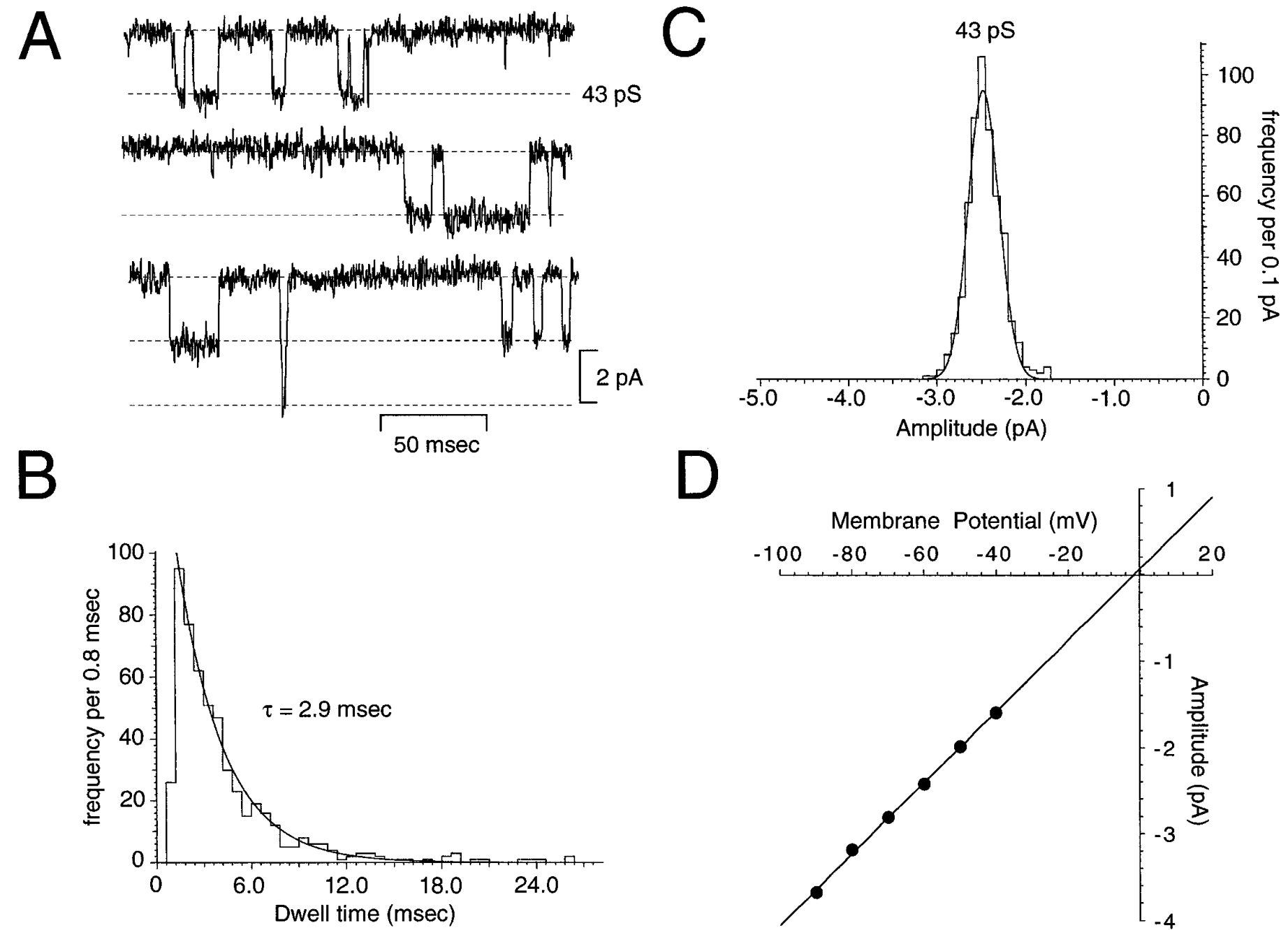

Figure 5. Whole-cell recordings of spontaneous NMDA receptor channel activity in mature NR2C $-/-$ granule cells are made up exclusively of large conductance events. $A$, A representative recording from a P16 - - mouse granule cell at $-60 \mathrm{mV}$. The open time $(B$, dwell time) and amplitudefrequency $(C)$ distributions were fit by single-component functions $(m=43 \mathrm{pS} ; \tau=2.9 \mathrm{msec})$. $D$, The single-channel currents displayed linear $I-V$ relations and reversed near $0 \mathrm{mV}$.

grams were best fit with a single exponential of a longer duration (Fig. $5 B$ ), which corresponded to the longer exponential observed in wild-type cells (Fig. 2B). This absence of small-amplitude, shorter-duration events also was observed in wild-type rat granule cells (Fig. $4 B)$ studied at an age range $(<\mathrm{P} 12)$ in which the expression of the NR2C subunit is known to be absent in the rat (Monyer et al., 1994) and mouse (Watanabe et al., 1992, 1994a,b). Excised patches from -/- mouse granule cells also displayed only the large-amplitude, long-duration opening events (Fig. 6).

\section{Mossy fiber-evoked macroscopic synaptic currents}

The electrical compactness of granule cells also allows one to examine single synaptically activated NMDA receptor channels under conditions in which relatively few channels are simultaneously open. This is the case for miniature EPSCs in granule cells (Silver et al., 1992) or for evoked EPSCs in the presence of competitive antagonists. In three granule cells of $-/-$ mice, flurries of channel opening events were observed after electrical stimulation of mossy fibers in the presence of D-AP5 $(10-22 \mu \mathrm{M})$,
CNQX $(10 \mu \mathrm{M})$, and bicuculline $(10 \mu \mathrm{M})$ (Fig. 7Aii-iv). In these cells, as in other recordings of $-/-$ mice (Figs. 5, 6), only largeamplitude, long-duration events were observed (Fig. 7B,C). In the cell illustrated in Figure 7, the conductance of the synaptically activated channels was identical to that of spontaneous channel events (open circles in Fig. 7B,C) and in an outside-out excised patch from the soma of the same cell (filled circles in Fig. $7 B, C$ ).

Whole-cell patch-clamp recordings of the mossy fiber-evoked macroscopic synaptic currents in mouse cerebellar granule cells of both wild-type $(+/+)$ and homozygous mutant $(-/-)$ animals revealed dual-component EPSCs similar in most respects to those observed previously in rat cerebellar granule cells (Fig. 8A,B) (Silver et al., 1992; D’Angelo et al., 1993, 1994; Rossi et al., 1995). The fast component of the EPSC in both cell types was blocked by the AMPA/KA receptor antagonist CNQX (10 $\mu \mathrm{M})$ (Figs. 8 $A, B$, $9 C)$ and exhibited fast activation $(10-90 \%$ rise time $=0.52 \mathrm{msec})$ and deactivation kinetics (Fig. 9B). This fast component was followed by a more slowly activating NMDA receptor-mediated 


\section{-/- Excised patch recording}
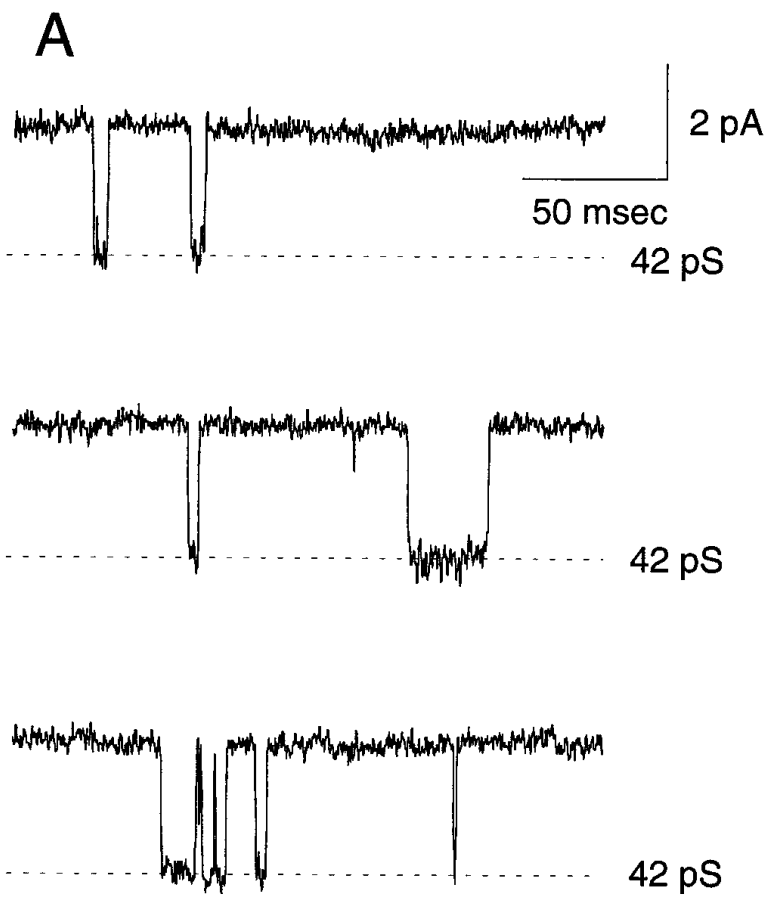

$42 \mathrm{pS}$

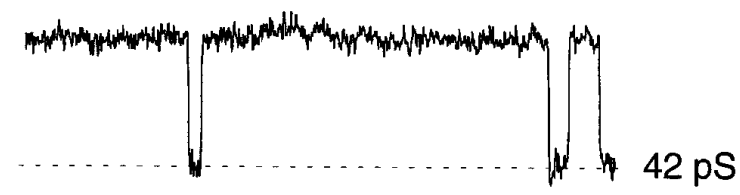

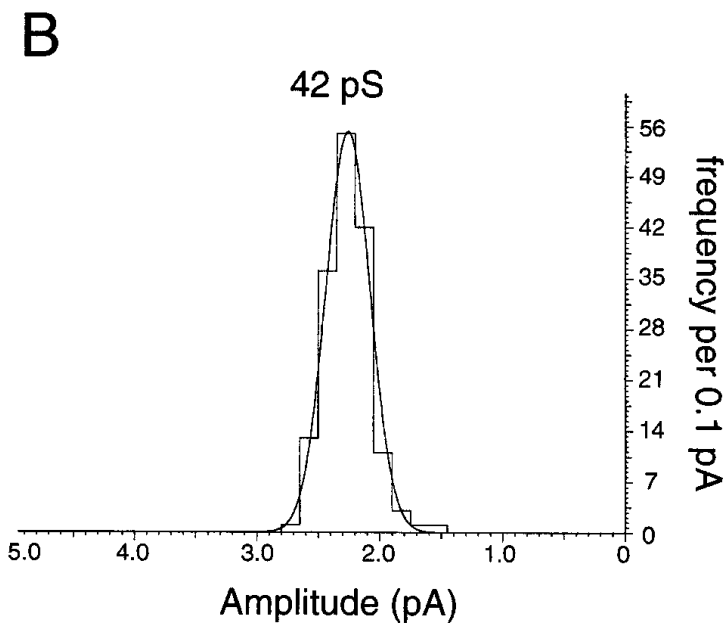

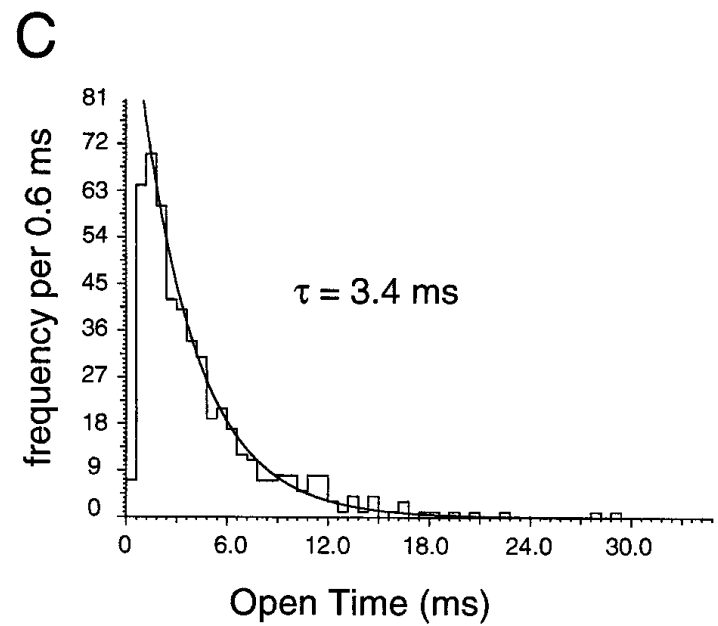

Figure 6. NMDA receptor channels in excised outside-out patches from mature NR2C $-/-$ granule cells lack low-conductance events. $A$, Single-channel currents activated by NMDA $(20 \mu \mathrm{M})$ applied to a patch excised from a P15 NR2C -/ - granule cell. Like the spontaneous channel openings observed in whole-cell recordings (Fig. 5), the NMDA-activated single-channel currents are made up exclusively of channels of large conductance $(B)$ and long mean open time $(C)$.

component, which could be blocked by extracellular $\mathrm{Mg}^{2+}(1 \mathrm{mM})$ and the NMDA receptor antagonists D-AP5 (50 $\mu \mathrm{M})$ (Fig. 9B) and 7-chlorokynurenate $(200 \mu \mathrm{M})$ (data not shown). When pharmacologically isolated in a medium containing CNQX $(10 \mu \mathrm{M})$ and glycine $(10 \mu \mathrm{M})$, the time course of the NMDA receptor-mediated EPSC of wild-type mouse granule cells (Fig. $8 A$, Table 1A) displayed a slow rise time $(10-90 \%=5.5 \mathrm{msec})$ and a biexponential decay $\left(\tau_{\mathrm{f}}=42.3 \mathrm{msec} ; \tau_{\mathrm{s}}=150.6 \mathrm{msec}\right)$, as observed previously in rat granule cells (D’Angelo et al., 1993, 1994).

Dual-component EPSCs also were readily observed in granule cells of knockout $(-/-)$ mice (Figs. $8 B, 9)$. The slow NMDA receptor-mediated synaptic currents were pharmacologically isolated in these cells (Figs. 8B,9), and their amplitude and time course compared with data obtained from cells in wild-type littermates (Fig. $8 A$ ). The rise times of both the AMPA/KA and NMDA receptor-mediated components were similar to those of wild-type animals (Table 1), but some significant differences in the synaptic currents also were observed (Fig. 8C,D). The most striking differences were the absolute amplitudes of the fast and slow components. In granule cells of homozygous mutant (-/-) mice, the mean amplitude of the NMDA receptor-mediated EPSC $(989 \pm 187 \mathrm{pS}, n=17)$ was more than twice the amplitude of the NMDA component observed in wild-type animals $(386 \pm 40 \mathrm{pS}$, $n=31)$. These differences were conserved $(p<0.0002)$ when other factors, such as small differences in the whole-cell capacitance (Table 2), were accounted for (Amplitude in Table 1A). This would suggest that there is an excess of NR2 subunits, and that they compete for a more limited number of NR1 subunits to form functional channels in the native membrane. Thus, deleting the more abundant NR2C subunits allows more NR2A subunits to form functional channels with a more limited number of available NR1 subunits, resulting in a larger ensemble current because of the larger unitary conductance of NR1-NR2A subunitcontaining channels. A reciprocal change was observed in the amplitude of the fast, AMPA/KA receptor-mediated component in homozygous mutant mice, being smaller $(641 \pm 219 \mathrm{pS}, n=34)$ than in wild-type mice of the same age group $(1174 \pm 151 \mathrm{pS}, n=$ $32 ; p<0.034)$. When corrected for the membrane surface area, 

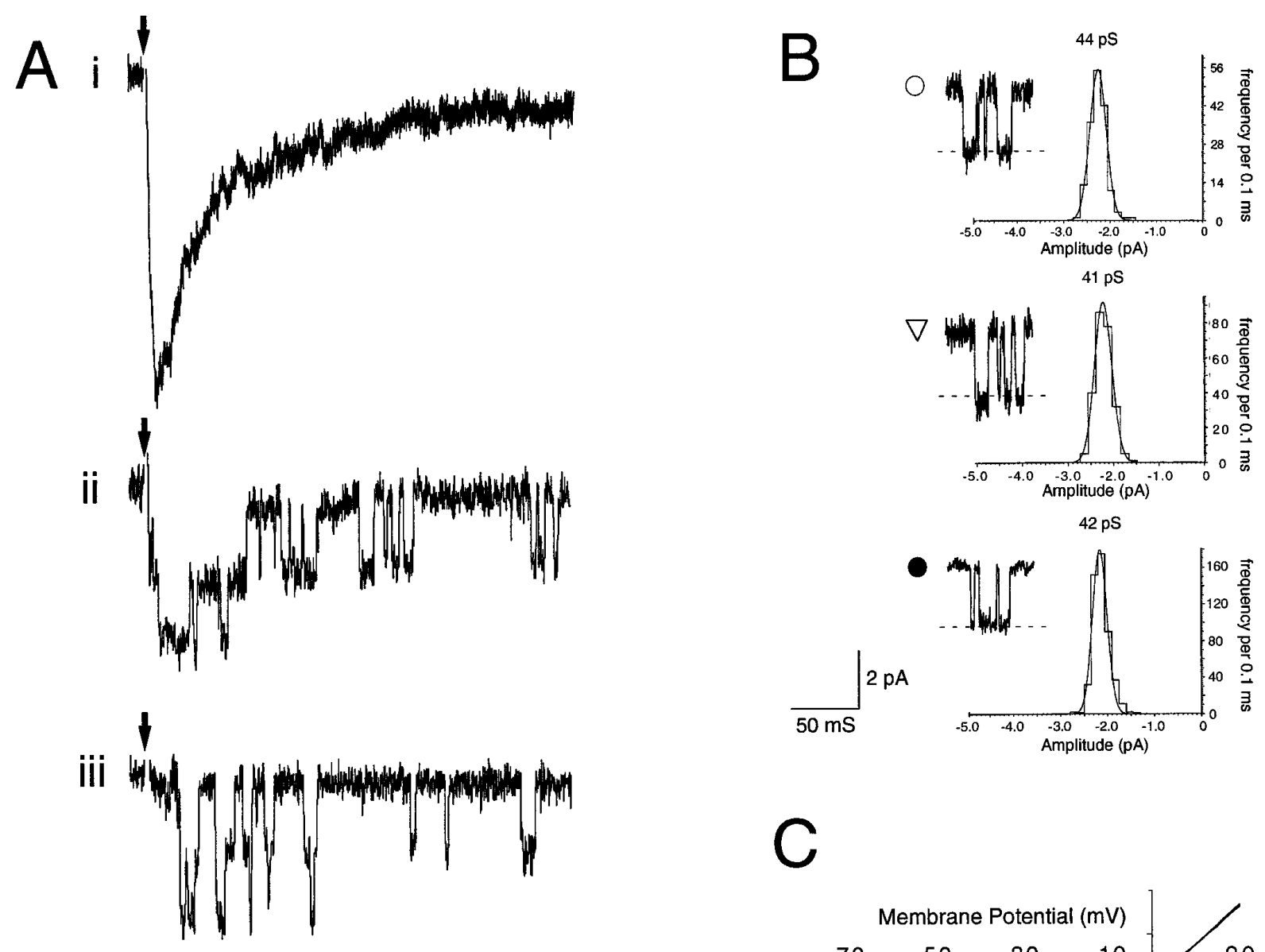

$42 \mathrm{pS}$
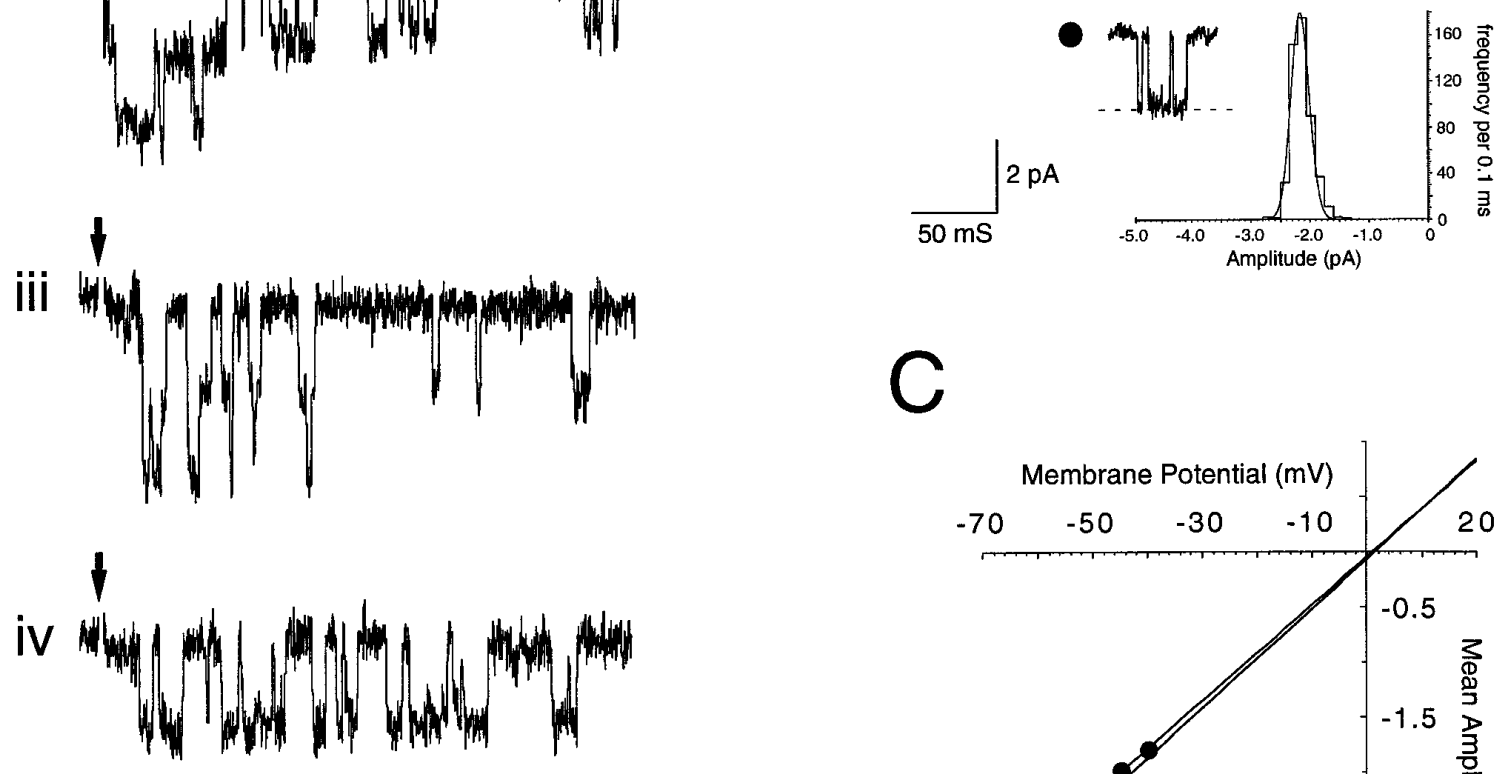

c
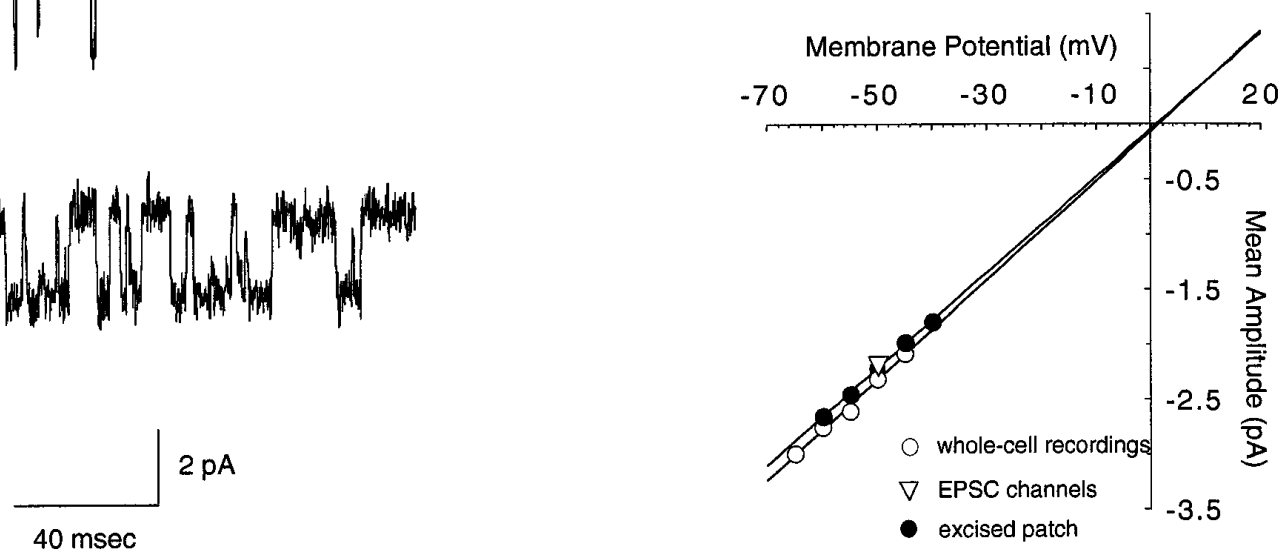

Figure 7. Synaptically activated single NMDA receptor channels of NR2C $-/-$ granule cells are made up exclusively of high-conductance events. $A$, In the presence of nonsaturating concentrations of the competitive NMDA receptor antagonist D-AP5, the pharmacologically isolated NMDA receptormediated mossy fiber-evoked EPSC ( $i$ ) (macroscopic EPSC recorded before the application of D-AP5) is made up of a flurry of directly resolvable single-channel openings $(i i-i v)$. These channels closely resemble the spontaneously active NMDA receptor channels $(B, C$, open circles), as well as the channels activated by NMDA in an excised patch from the same cell $(B, C$, filled circles) and do not appear to express any small-conductance openings. The complete lack of small-conductance openings at any cellular locus argues against a nonspecific effect of localization. The similarity of synaptic and somatic channels lends credence to inferences about synaptic currents based on somatic receptors in preparations in which synaptic receptors are not as accessible.

the current density of the peak of the fast component was significantly smaller in homozygous mutant mice $(205 \pm 56 \mathrm{pS} / \mathrm{pF} ; p<$ $0.05)$ than in wild-type mice $(434 \pm 65 \mathrm{pS} / \mathrm{pF})$. The time course of the NMDA receptor-mediated synaptic current in homozygous mutant mice also displayed a biexponential decay (Fig. 9D), as in wild-type animals, but the time constant of the fast component of decay was reduced significantly $(23.0 \pm 2.9 \mathrm{msec}, n=50 ; p<$ $0.001)$ compared with wild-type littermates $(42.3 \pm 6.0 \mathrm{msec}, n=$ 49). A shift of the relative amplitudes of these two components of decay also was observed $(\mathrm{F} / \mathrm{S}$ in Table 1$)$, with a significant increase in the amplitude of the fast component of decay in -/animals (Table 1).

These differences in amplitude and time course of the NMDA receptor-mediated component result in a synaptic current of smaller peak amplitude, but longer duration in $+/+$ animals (Fig. $8 C$ ). Consequently, the total charge passed was nearly identical in each cell type $\left(Q_{\text {total }}\right.$ in Table 1$)$. The differences in the NMDA currents, when combined with the antipodal changes in the AMPA currents, result in composite EPSCs of markedly different time course, the most obvious consequence being a more promi- 

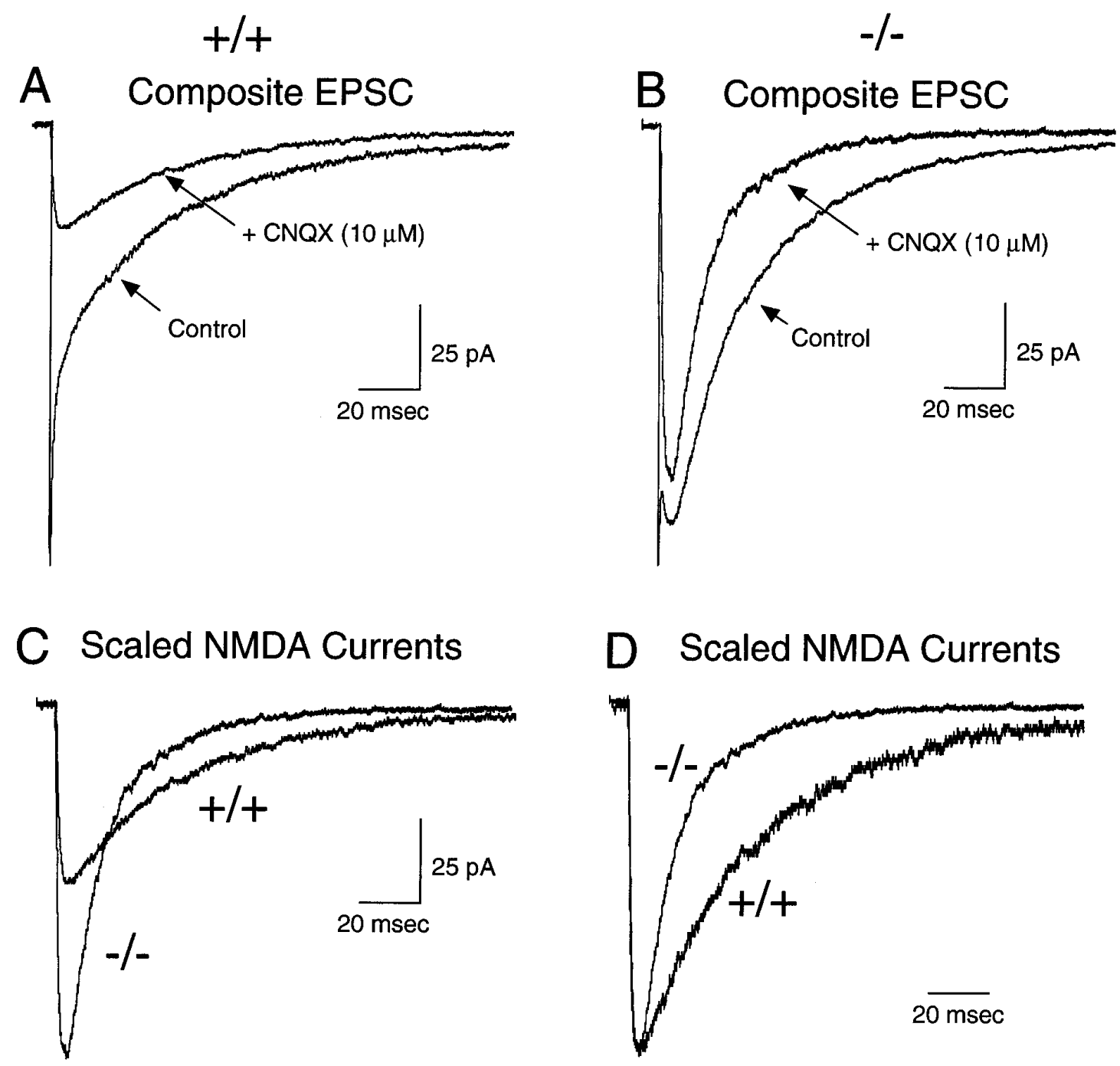

\section{Scaled NMDA Currents}

Figure 8. Mossy fiber-evoked macroscopic EPSCs in wild-type (+/+) and NR2C -/- granule cells. $A, B$, The composite mossy fiber-evoked EPSCs of granule cells in wild-type $(+/+)$ and NR2C-deficient $(-/-)$ mice recorded under control conditions $(\mathrm{Control})$ and in the presence of CNQX $(10 \mu \mathrm{M})$ and glycine $(10 \mu \mathrm{M})$ to pharmacologically isolate the NMDA receptor-mediated component. $C$, The NMDA receptor-mediated components from the cells illustrated in $A$ and $B$ are superimposed, with the relative amplitudes vertically scaled to the mean observed in all cells (Table 1A) to illustrate the similarity of the net charge in the two cell types. $D$, The NMDA receptor-mediated currents from the cells illustrated in $A$ and $B$ are superimposed with their amplitudes scaled to the same peak, to illustrate the faster rate of decay of the synaptic current in granule cells from NR2C $-/-$ mice.

nent late, NMDA receptor-mediated component of the EPSC of $-/-$ granule cells (Fig. 8B).

The fact that the two components of the EPSC vary in opposite directions argues strongly against the observed differences being attributable to differential distortion by passive properties of the cell. Furthermore, the passive properties capable of distorting the kinetics of the synaptic current (access resistance, input resistance, whole-cell capacitance, and series resistance error) did not differ significantly between the two cell types (Table 2). Finally, none of the measured parameters of the synaptic current (amplitude and exponential decay values) displayed any correlation with passive properties (access resistance, input resistance, capacitance, and series resistance error) of the recordings.

\section{DISCUSSION}

\section{Expression of the NR2C gene results in NMDA} receptor channels with distinct biophysical properties

The results of these experiments demonstrate directly that the appearance of NMDA receptor channels of low unitary conduc- tance and short mean open time in the third postnatal week is dependent on the developmental expression of the NR2C subunit gene product. This had been proposed previously (Farrant et al., 1994) based on the observation that low-conductance channels are first observed at the same developmental period when mRNAs for the NR2C subunit are detected by in situ hybridization methods (Watanabe et al., 1992, 1994a,b; Monyer et al., 1994), and in recombinant expression systems low-conductance channels are observed when NR1 and NR2C are co-expressed (Stern et al., 1992). When the gene encoding the NR2C subunit was deleted, no low-conductance channels were observed (Figs. 4B, 5-7) at a postnatal period when these were expressed in wild-type littermates (Figs. 2, 3, 4A). These data would, therefore, strongly support the hypothesis that the developmental expression of lowconductance NMDA receptor channels during granule cell maturation is controlled by the gene encoding the NR2C subunit. Furthermore, it would appear that the subunit composition of NMDA receptor channels in situ displays similar biophysical prop- 


\section{Synaptic currents in -/- granule cells}
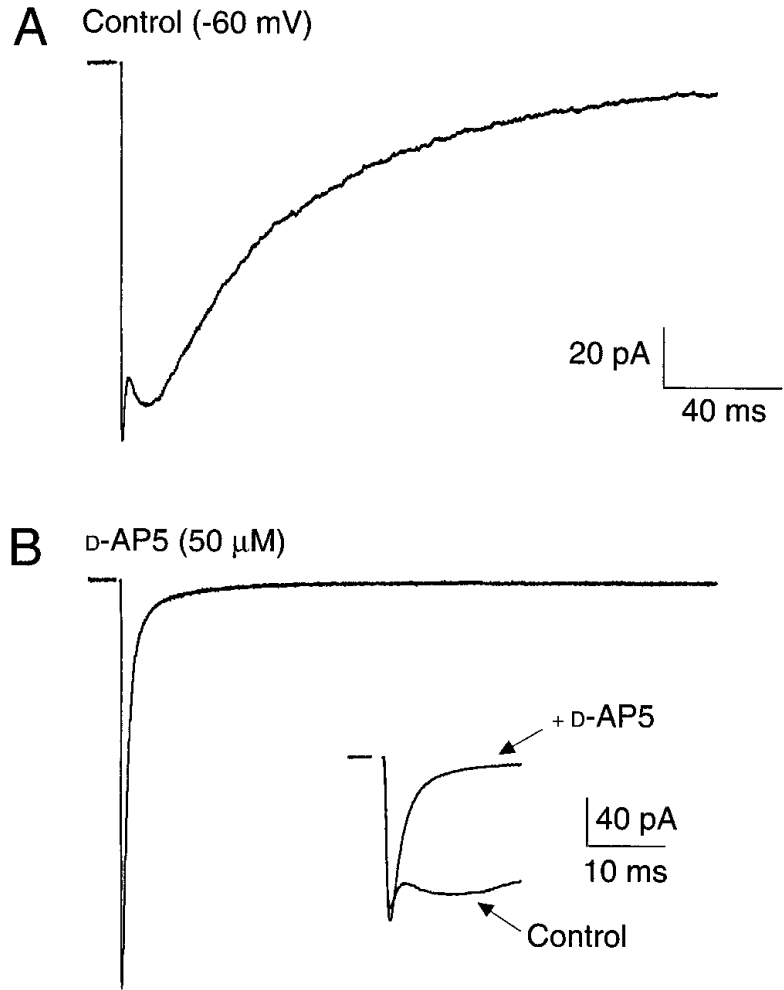
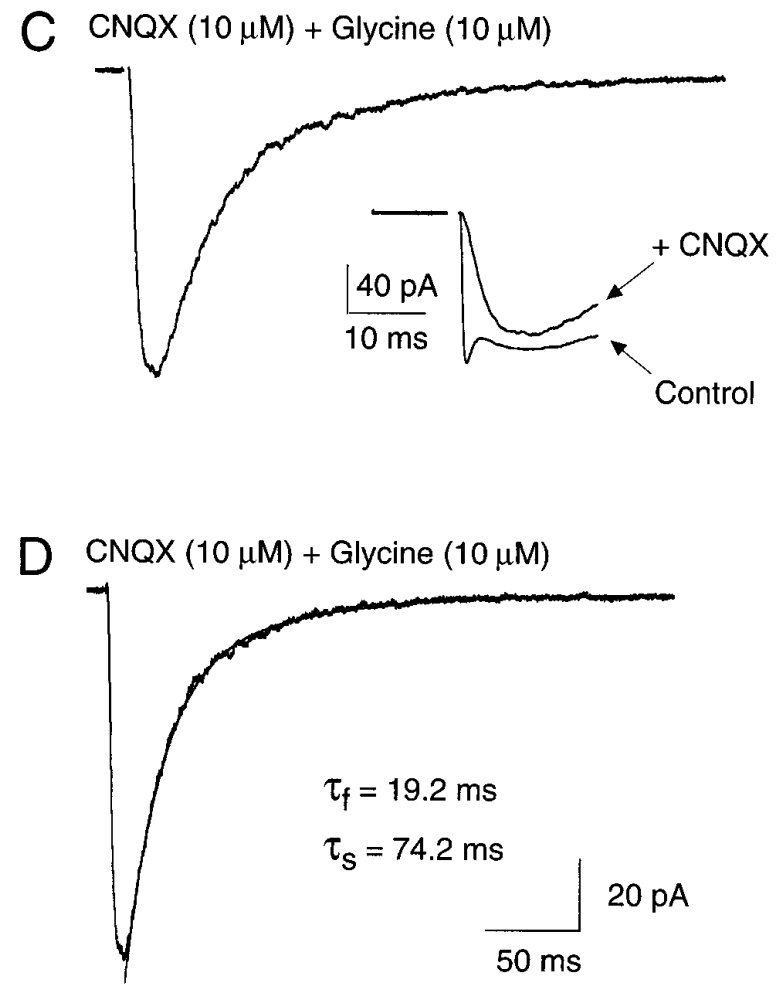

Figure 9. Properties of the mossy fiber-evoked EPSC in homozygous mutant mouse granule cells. $A$, The mossy fiber-evoked composite EPSC under control conditions [ $-60 \mathrm{mV}, 0 \mathrm{Mg}^{2+}$, bicuculline $\left.(10 \mathrm{mM})\right]$. The AMPA receptor- and NMDA receptor-mediated components of the composite EPSC can be resolved independently by the application of D-AP5 $(50 \mu \mathrm{M})$ to illustrate the fast, AMPA receptor-mediated component $(B)$, or the application of CNQX $(10 \mu \mathrm{M})$ and glycine $(10 \mu \mathrm{M})$ after recovery from D-AP5 to illustrate the NMDA receptor-mediated component $(C)$. Insets in $B$ and $C$ are faster time-base records with the control trace overlaid. All traces are from the same NR2C - / - mouse granule cell (P17). In $D$, the pharmacologically isolated NMDA receptor-mediated EPSC is displayed at a slightly higher gain and slower time base to display the biexponential decay of the EPSC; fit is overlaid as a solid line.

erties to that observed in recombinant expression systems (Stern et al., 1992).

\section{Individual NMDA receptor channels may contain multiple NR2 subunit forms}

NMDA receptor channels of mature wild-type granule cells displayed a wide range of unitary conductances (Fig. $4 A$ ). Although the range of conductances for the whole population of cells appeared to approximately vary around two distinct means $(\sim 32$ and $\sim 42 \mathrm{pS}$ ) (Fig. $4 A$ ), many individual cells also exhibited more than two clearly distinct populations of conductance states (Fig. $3 i$ ). As many as five clearly separable conductance states could be observed in a single cell. This wide range of conductance states has not been reported for recombinantly expressed NMDA receptors containing just the NR1 and one type of NR2 subunit (Stern et al., 1992; Tsuzuki et al., 1994), but has been reported in situ (Cull-Candy and Usowicz, 1987, 1989; Jahr and Stevens, 1987; Ascher et al., 1988). Some of this variability is likely created by subconductance states of a single channel, because direct transitions between two conductance states have been reported for NMDA receptors in situ (Jahr and Stevens, 1987; Cull-Candy and Usowicz, 1989; Howe et al., 1991) and when recombinantly expressed (Stern et al., 1992; Tsuzuki et al., 1994). In the present study, clear direct transitions between two conductance states also were observed (data not shown). However, some cells exhibited approximately equal distributions of up to four distinct conductance states with few direct transitions. Although a statistical analysis of the frequency of direct transitions and isolated openings to different conductance states was not performed, it seems unlikely that all of the variability is attributable to subconductance states alone. An interesting alternative is that NMDA receptors in mature granule cells are multimeric complexes with varying stochiometric ratios of the NR2A and NR2C subunits. Immunoprecipitation and protein cross-linking studies have suggested that endogenous NMDA receptors can be made up of trimeric complexes of NR1-NR2A-NR2B (Sheng et al., 1994) or NR1NR2A-NR2C (Chazot et al., 1994). Additionally, the affinity profile of mature granule cell NMDA receptors in situ for MK-801 and related compounds most closely resembles that of recombinantly expressed NMDA receptors containing the NR1, NR2A, and NR2C subunits (Chazot et al., 1994). Therefore, it may be that the different conductance levels seen here in granule cells of wild-type mice may represent NMDA receptor channels with differing proportions of NR2A and NR2C. The large conductance events presumably would reflect the opening of channels made up of NR1 and NR2A alone, whereas the smallest conductance events may reflect the activity of NR1- and NR2C-containing receptors, and channels with intermediate conductance levels represent complexes with all three subunits in varying stochiometries. 
Table 1. Excitatory synaptic currents in mouse cerebellar granule cells

\begin{tabular}{|c|c|c|c|c|c|c|c|}
\hline \multirow[b]{2}{*}{ Cell type } & \multirow{2}{*}{$\begin{array}{l}\text { Rise time (msec) } \\
10-90 \%\end{array}$} & \multirow{2}{*}{$\begin{array}{l}\text { Amplitude* } \\
(\mathrm{pS} / \mathrm{pF})\end{array}$} & \multirow{2}{*}{$\begin{array}{l}Q_{\text {total }} \\
(\mathrm{pC})\end{array}$} & \multirow{2}{*}{$\begin{array}{l}\text { Decay time }(\mathrm{msec})^{*} \\
10-90 \%\end{array}$} & \multicolumn{2}{|c|}{ Decay rate $(\mathrm{msec})$} & \multirow[b]{2}{*}{$\mathrm{F} / \mathrm{S}^{b}$} \\
\hline & & & & & $\tau_{\text {fast }}^{*}$ & $\tau_{\text {slow }}$ & \\
\hline \multicolumn{8}{|c|}{ A. Properties of pharmacologically isolated NMDA receptor-mediated EPSCs ${ }^{a}$} \\
\hline$+/+$ & $5.5 \pm 0.8$ & $135.3 \pm 15.1$ & $4.3 \pm 1.1$ & $211.6 \pm 22$ & $42.3 \pm 6.0$ & $150.6 \pm 8.8$ & $1.5 \pm 0.5$ \\
\hline$-1-$ & $5.0 \pm 0.4$ & $278.5 \pm 42.1$ & $4.2 \pm 0.9$ & $114.3 \pm 22$ & $23.0 \pm 2.9$ & $184.0 \pm 43.5$ & $3.9 \pm 1.0$ \\
\hline \multirow[b]{2}{*}{ Cell type } & \multirow{2}{*}{$\begin{array}{l}\text { Rise time (msec) } \\
10-90 \%\end{array}$} & \multirow{2}{*}{$\begin{array}{l}\text { Amplitude* } \\
(\mathrm{pS} / \mathrm{pF})\end{array}$} & \multirow{2}{*}{$\begin{array}{l}Q_{\text {total }} \\
(\mathrm{pC})\end{array}$} & \multirow{2}{*}{$\begin{array}{l}\text { Decay time }(\mathrm{msec})^{*} \\
10-90 \%\end{array}$} & \multicolumn{2}{|c|}{ Decay rate $(\mathrm{msec})$} & \multirow[b]{2}{*}{$\mathrm{F} / \mathrm{S}^{b}$} \\
\hline & & & & & $\tau_{\text {fast }}{ }^{*}$ & $\tau_{\text {slow }}$ & \\
\hline \multicolumn{8}{|c|}{ B. Properties of mossy fiber-evoked synaptic currents } \\
\hline$+/+$ & $0.46 \pm 0.04$ & $434.6 \pm 65.0$ & $8.0 \pm 1.8$ & $270.6 \pm 49.5$ & $44.3 \pm 6.5$ & $199.6 \pm 24.2$ & $1.5 \pm 0.4$ \\
\hline$-1-$ & $0.50 \pm 0.02$ & $205.2 \pm 56.6$ & $6.4 \pm 1.2$ & $165.6 \pm 23.3$ & $32.4 \pm 3.5$ & $303.0 \pm 51.0$ & $4.9 \pm 1.2$ \\
\hline
\end{tabular}

All data are given as mean \pm SE. Data are derived from measurements of 17-51 granule cells in each group.

${ }^{a}$ NMDA receptor-mediated synaptic currents were recorded in the presence of CNQX $(10 \mu \mathrm{M})$ and glycine $(10 \mu \mathrm{M})$.

${ }^{b} \mathrm{~F} / \mathrm{S}$ represents the ratio of the amplitudes of the fast (F) and slow (S) exponential components of decay of the EPSC.

*Denotes statistically significant difference $(p<0.05$, Student's $t$ test).

\section{NMDA receptor channels containing the NR2C subunit are tonically activated}

The function of the NR2C subunit was assessed by comparing some of the properties of NMDA receptor-mediated currents in transgenic mice with those of age-matched wild-type mice. With the confirmation that the small conductance openings indeed result from the expression of the NR2C subunit, it can be concluded that NMDA receptors containing the NR2C subunit are, like their NR2A-containing counterparts, tonically activated by endogenous glutamate (Fig. 2). There is good evidence that the tonic activation of NMDA receptors influences biochemical differentiation (Moran and Patel, 1989), neuronal migration (Komuro and Rakic, 1993), and neurite outgrowth (Pearce et al., 1987 ) in granule cells. The tonic activation of NMDA receptors in vivo will be controlled by the interaction of many factors including ambient glutamate and glycine concentration, and also by the voltage-dependent block of NMDA receptor channels by external $\mathrm{Mg}^{2+}$. NMDA receptor channels that contain the NR2C subunit are less sensitive to $\mathrm{Mg}^{2+}$ (Mishina et al., 1993; Monyer et al., 1994) and more sensitive to glycine than NR2A-containing receptors (Stern et al., 1992; Mishina et al., 1993). NR2C-containing receptors also are less susceptible to desensitization (Monyer et al., 1994). Consequently, NR2C subunit-containing receptors will be more likely to pass current in a given physiological situation. The developmental expression of the NR2C subunit may therefore reflect in part changing requirements for tonic activation as well as synaptic transmission.

\section{Expression of the NR2C subunit modifies synaptic currents}

The expression of the NR2C subunit appears to affect several aspects of the mossy fiber-granule cell EPSC. Thus, in $-/-$ mice, the NMDA receptor-mediated EPSC was of a significantly larger

\begin{tabular}{|c|c|c|c|c|}
\hline $\begin{array}{l}\text { Cell } \\
\text { type }\end{array}$ & $\begin{array}{l}R_{\mathrm{a}} \\
(\mathrm{M} \Omega)\end{array}$ & $\begin{array}{l}R_{\mathrm{i}} \\
(\mathrm{G} \Omega)\end{array}$ & $\begin{array}{l}\% R_{\mathrm{s}} \\
\left(R_{\mathrm{a}} / R_{1} * 100\right)\end{array}$ & $\begin{array}{l}\text { Capacitance } \\
(\mathrm{pF})\end{array}$ \\
\hline$+1+$ & $73.7 \pm 5.9$ & $4.9 \pm 0.5$ & $1.9 \pm 0.3$ & $3.1 \pm 0.2$ \\
\hline$-1-$ & $61.7 \pm 3.5$ & $7.3 \pm 1.6$ & $1.2 \pm 0.2$ & $3.5 \pm 0.4$ \\
\hline
\end{tabular}

$\overline{R_{\mathrm{a}}, \text { Access resistance; } R_{\mathrm{i}} \text {, cell input resistance; } R_{\mathrm{s}} \text {, series resistance error. None of the }}$ differences was statistically significant (ANOVA, $p>0.5$ ). amplitude but shorter duration than EPSCs of wild-type peers (Fig. 8; Table 1A). Surprisingly, the non-NMDA receptorcomponent of the EPSC was significantly smaller in the $-/-$ mice (Table 1B). The net result of these changes is a dramatically different EPSC profile (Fig. 8).

It might appear paradoxic that eliminating the expression of NR2C, which is heavily expressed in granule cells with maturation, should result in an EPSC with a larger peak amplitude. However, these observed changes in the time course of the NMDA receptor-mediated EPSC in $-/-$ animals, in which the EPSC is presumably mediated by receptors composed exclusively of NR1NR2A subunits, are readily explicable. If the inclusion of one or more NR2C subunits in a multimeric receptor-channel complex result in a reduced unitary conductance and shorter open time, as the single-channel data would suggest, then the amplitude and time course of EPSCs of granule cells in $+/+$ animals will reflect these properties. At the peak of the ensemble current, most NMDA receptors will be bound by glutamate, and the absolute value of the macroscopic current will reflect the opening probability and mean conductance of the channels that open.

The reduced amplitude of the fast, AMPA receptor-mediated component of the EPSC in homozygous mutants is less intuitive. One possible explanation is that the tonic activation of calciumpermeable, NR2C-containing receptors modulates the density or subunit composition of AMPA receptors at the synapse. This could occur through the participation of calcium in the activation of immediate early genes, which in turn regulate the expression of genes coding for AMPA receptors.

The net result of the elimination of the expression of the NR2C subunit is a composite EPSC (Figs. 8, 9A), which is strikingly similar to the EPSC of immature wild-type granule cells (D'Angelo et al., 1993). This would be expected, because NMDA receptor channels of the mutant presumably have the same molecular composition as those of immature wild-type neurons. This would infer that the maturational changes in synaptic currents in these neurons are governed principally by the expression of the $\mathrm{NR} 2 \mathrm{C}$ gene and incorporation of the gene product into assembled receptor channels in the membrane. The previous switch in expression of NR2B to NR2A, which accompanies synapse formation in the initial postmigratory period, likely subserves different physiological requirements. NR1-NR2B-containing receptor channels do not desensitize readily and are well suited to partic- 
ipate in the migration of neurons, which is mediated in part by the tonic activation of NMDA receptors by resting glutamate concentrations in the extracellular space (Komura and Rakic, 1993; Rossi and Slater, 1993; Slater and Rossi, 1996). As synapse formation occurs, NR2B subunits are replaced by NR2A, which display faster desensitization kinetics (Monyer et al., 1992, 1994), which may be better suited to participate in transmission. The sequential expression of the genes coding for these three NMDA receptor subunits during development and maturation thus produces an elegant concert of events that result in the expression of NMDA receptor channels tailored in their kinetic properties to the physiological roles they play. Because activation of more than one afferent mossy fiber is required to evoke an action potential in granule cells (D'Angelo et al., 1995), the increased duration of the EPSC in mature cells (expressing NR2C) will enhance the probability of temporal summation of individual EPSCs and, thus, increase the efficacy of cooperative transmission.

\section{REFERENCES}

Ascher P, Bregestovski P, Nowak L (1988) $N$-methyl-D-aspartateactivated channels of mouse central neurones in magnesium-free solutions. J Physiol (Lond) 399:207-226.

Bear MF, Malenka RC (1994) Synaptic plasticity: LTP and LTD. Curr Opin Neurobiol 4:389-399.

Bliss TVP, Collingridge GL (1993) A synaptic model of memory: longterm potentiation in the hippocampus. Nature 361:31-39.

Bradley A (1987) Production and analysis of chimeric mice. In: Teratocarcinomas and embryonic stem cells: a practical approach (EJ Robertson, ed), pp 113-151. Oxford: IRL.

Chazot PL, Coleman SK, Cik M, Stephenson FA (1994) Molecular characterization of $N$-methyl-D-aspartate receptors expressed in mammalian cells yields evidence for the coexistence of three subunit types within a discrete receptor molecule. J Biol Chem 269:24403-24409.

Constantine-Paton M, Cline HT, Debski E (1990) Patterned activity, synaptic convergence, and the NMDA receptor in developing visual pathways. Annu Rev Neurosci 13:129-154.

Cull-Candy SG, Usowicz MM (1987) Multiple-conductance channels activated by excitatory amino acids in cerebellar neurons. Nature 325:525-528.

Cull-Candy SG, Usowicz MM (1989) On the multiple-conductance single channels activated by excitatory amino acids in large cerebellar neurones of the rat. J Physiol (Lond) 415:555-582.

D'Angelo E, Rossi P, Taglietti V (1993) Different proportions of $N$-methyl-D-aspartate and non- $N$-methyl-D-aspartate receptor currents at the mossy fibre-granule cell synapse of developing rat cerebellum. Neuroscience 53:121-130.

D’Angelo E, Rossi P, Taglietti V (1994) Voltage-dependent kinetics of $N$-methyl-D-aspartate synaptic currents in rat cerebellar granule cells. Eur J Neurosci 6:640-645.

D'Angelo E, De Filippi G, Rossi P, Taglietti V (1995) Synaptic excitation of individual rat cerebellar granule cells in situ: evidence for the role of NMDA receptors. J Physiol (Lond) 484:397-413.

Edwards FA, Konnerth A, Sakmann B, Takahashi T (1989) A thin slice preparation for patch clamp recording from neurones of the mammalian central nervous system. Pflügers Arch 414:600-612.

Farrant M, Feldmeyer D, Takahashi T, Cull-Candy SG (1994) NMDAreceptor channel diversity in the developing cerebellum. Nature 368:335-339.

Gabbiani F, Midtgaard J, Knöpfel T (1994) Synaptic integration in a model of cerebellar granule cells. J Neurophysiol 72:999-1009.

Garthwaite J (1994) NMDA receptors, neuronal development, and neurodegeneration. In: The NMDA receptor, 2nd ed (Collingridge GL, Watkins JC, eds), pp 428-456. Oxford: Oxford UP.

Gibb AJ, Colquhoun D (1992) Activation of $N$-methyl-D-aspartate receptors by L-glutamate in cells dissociated from adult rat hippocampus. J Physiol (Lond) 456:143-179.

Howe JR, Cull-Candy SG, Colquhoun D (1991) Currents through single glutamate-receptor channels in outside-out patches from rat cerebellar granule cells. J Physiol (Lond) 432:143-202.
Jahr CE, Stevens CF (1987) Glutamate activates multiple single channel conductances in hippocampal neurons. Nature 325:522-525.

Komuro H, Rakic P (1993) Modulation of neuronal migration by NMDA receptors. Science 260:95-97.

Kutsuwada T, Kashiwabuchi N, Mori H, Sakimura K, Kushiya E, Araki K, Meguro H, Masaki H, Kumanishi T, Arakawa M, Mishina M (1992) Molecular diversity of the NMDA receptor channel. Nature 358:36-41.

Marty A, Neher E (1983) Tight-seal whole-cell recording. In: Singlechannel recording (Sakmann B, Neher E, eds), pp 107-122. New York: Plenum.

McMahon AP, Bradley A (1990) The Wnt-1 (int-1) protooncogene is required for development of a large region of the mouse brain. Cell 62:1073-1085.

Meguro H, Mori H, Araki K, Kushiya E, Kutsuwada T, Yamazaki M, Kumanishi T, Arakawa M, Sakimura K, Mishina M (1992) Functional characterization of a heteromeric NMDA receptor channel expressed from cloned cDNAs. Nature 357:70-74.

Mishina M, Mori H, Araki K, Kushiya E, Meguro H, Kutsuwada T, Kashiwabuchi N, Ikeda K, Nagasawa M, Yamazaki M, Masaki H, Yamakura T, Morita T, Sakimura K (1993) Molecular and functional diversity of the NMDA receptor channel. Ann NY Acad Sci 707:136-152.

Monyer H, Sprengel R, Schoepfer R, Herb A, Higuchi M, Lomeli H, Burnashev N, Sakmann B, Seeburg P (1992) Heteromeric NMDA receptors: molecular and functional distinction of subtypes. Science 256:1217-1221.

Monyer H, Burnashev N, Laurie DJ, Sakmann B, Seeburg PH (1994) Developmental and regional expression in the rat brain and functional properties of four NMDA receptors. Neuron 12:529-540.

Moran J, Patel AJ (1989) Stimulation of the $N$-methyl-D-aspartate receptor promotes the biochemical differentiation of cerebellar granule neurons and not astrocytes. Brain Res 486:15-25.

Mugnaini E, Atluri RL, Houk JC (1974) Fine structure of the granular layer in turtle cerebellum with emphasis on large glomeruli. J Neurophysiol 37:1-29.

Pearce IA, Cambray-Deakin MA, Burgoyne RD (1987) Glutamate acting on NMDA receptors stimulates neurite outgrowth from cerebellar granule cells. FEBS Lett 223:143-147.

Rossi DJ, Slater NT (1993) The developmental onset of NMDA receptor-channel activity during neuronal migration. Neuropharmacology 32:1239-1248.

Rossi DJ, Alford S, Mugnaini E, Slater NT (1995) Properties of transmission at a giant glutamatergic synapse in cerebellum: the mossy fiber-unipolar brush cell synapse. J Neurophysiol 74:24-42.

Sheng M, Cummings J, Roldan LA, Jan YN, Jan LY (1994) Changing subunit composition of heteromeric NMDA receptors during development of rat cortex. Nature 368:144-147.

Silver RA, Traynelis SF, Cull-Candy SG (1992) Rapid-time-course miniature and evoked excitatory currents at cerebellar synapses in situ. Nature 355:163-166.

Slater NT, Rossi DJ (1996) Functional expression of NMDA receptors in developing neurons. In: Excitatory amino acids and the cerebral cortex (Conti F, Hicks TP, eds), pp 215-226. Boston: MIT.

Stern P, Behe P, Schoepfer R, Colquhoun D (1992) Single-channel conductances of NMDA receptors expressed from cloned cDNAs: comparison with native receptors. Proc R Soc Lond [Biol] 250:271-277.

Tsuzuki K, Mochizuki S, Iino M, Mori H, Mishina M, Ozawa S (1994) Ion permeation properties of the cloned mouse $\epsilon 2 / \omega 1$ NMDA receptor channel. Mol Brain Res 26:37-46.

Watanabe M, Inoue Y, Sakimura K, Mishina M (1992) Developmental changes in distribution of NMDA receptor channel subunit mRNAs. NeuroReport 3:1138-1140.

Watanabe M, Inoue Y, Sakimura K, Mishina M (1994a) Distinct spatiotemporal distributions of the NMDA receptor channel subunit mRNAs in the brain. Ann NY Acad Sci 707:463-466.

Watanabe M, Mishina M, Inoue Y (1994b) Distinct spatiotemporal expressions of five NMDA receptor channel subunit mRNAs in the cerebellum. J Comp Neurol 343:513-519.

Wo ZG, Oswald RE (1995) Unraveling the modular design of glutamategated ion channels. Trends Neurosci 18:161-168.

Wood MW, VanDongen HMA, VanDongen AMJ (1995) Structural conservation of ion conduction pathways in $\mathrm{K}$ channels and glutamate receptors. Proc Natl Acad Sci USA 92:4882-4886. 